\title{
KEEFEKTIFAN MOBILE LEARNING MEDIA BERMUATAN ETHNOSCIENCE TERHADAP HASIL BELAJAR SISWA SEKOLAH DASAR
}

\author{
Dian Marta Wijayanti, Farid Ahmadi, Sarwi \\ girlsmarta@gmail.com,faried_it@yahoo.com,sarwi_dosen@mail.unnes.ac.id \\ Pendidikan Dasar, Universitas Negeri Semarang
}

\begin{abstract}
:
Era Revolusi Industri 4.0 dan Society 5.0 mengharuskan pembelajaran di Sekolah Dasar harus menyesuaikan zaman. Salah satu bentuknya dengan mengembangkan media pembelajaran berbasis digital. Tujuan penelitian ini untuk mengukur keefektifan mobile learning media bermuatan ethnoscience terhadap hasil belajar siswa sekolah dasar. Metode penelitian yang digunakan adalah penelitian eksperimen dengan menggunakan uji t-test. Temuan penelitian menunjukkan bahwa nilai thitung $>$ ttabel (ttable $=$ 2,045) dan signifikansi $<0,05$. Karena $7.718>2,045$ dan 0,001<0,05, maka hipotesis diterima yang berarti bahwa nilai kelas eksperimen lebih baik daripada nilai kelas kontrol. Jadi, dapat disimpulkan bahwa Mobile Learning Media bermuatan Ethnoscience efektif untuk digunakan di sekolah dasar.
\end{abstract}

Kata Kunci: Mobile Learning Media, Ethnoscience, Sekolah Dasar

\section{PENDAHULUAN}

Di era Revolusi Industri 4.0 dan Society 5.0, pembelajaran di jenjang SD/MI harus menyesuaikan zaman. Pasalnya, mereka tidak sekadar dituntut menguasai keterampilan literasi lama (membaca, menulis, berhitung) namun juga dituntut menguasai literasi baru (literasi data, teknologi, dan manusia).

Hal ini sesuai riset yang ada bahwa literasi tidak sekadar tentang baca, tulis saja literasi baca tulis, namun di jenjang pendidikan dasar dibutuhkan literasi sains, literasi teknologi informasi, dan literasi finansial (Ibda, 2018:1). Dalam pembelajaran di SD saat ini sudah menggunakan teknologi digital seperti aplikasi edukatif. Aplikasi yang digunakan dalam pemeblajaran tersebut selain memudahkan guru juga berpengaruh terhadap hasil belajar.

Saat ini dunia pendidikan dan pelatihan sangat bergantung pada industri teknologi digital dan internet. Fenomena ini merupakan hal positif bagi stakeholders mulai dari guru, kepala sekolah, tenaga kependidikan, orang tua, dan siswa untuk menyesuaikan era digital (Prawiradilaga, 2012, p. 272). Maka dari itu, mau tidak mau guru SD harus mampu menyesuaikan zaman dengan memanfaatkan teknologi digital dalam pembelajaran.

Teknologi digital terbukti mampu mendukung kegiatan pembelajaran di kelas. Salah satu bentuk penggunaan teknologi digital tersebut berupa pemanfaatan mobile learning media. Bentuk media ini mampu menjembatani keterbatasan waktu yang 
dimiliki guru untuk bertatap muka di dalam kelas dapat diatasi dengan cara daring (dalam jaringan). Secara konseptual mobile learning merupakan penyampaian bahan pembelajaran elektronik pada alat komputasi mobile yang dapat diakses dari mana saja dan kapan saja (Ally, 2009:1).

Mobile Learning Media dari beberapa riset terbukti mampu meningkatkan hasil belajar siswa di Sekolah Dasar. Penelitian (Nasution, 2016: 13) tentang penggunaan mobile learning media di kelas 1 Sekolah Dasar sebanyak 80 persen peserta didik merasa terbantu dalam meningkatkan kemauan dan kemajuan belajar membaca dengan memnfaatkan mobile learning yang dibuat oleh guru. Pembelajaran dengan mobile learning lebih menyenangkan karena dibuat dengan bahan-bahan ajar yang lebih interaktif sehingga siswa termotivasi untuk belajar.

Mobile learning memungkinkan pendidik dan peserta didik dapat melaksanakan pembelajaran melampaui kelas tradisional (kelas ruang tutorial, laboratorium, dan ruang teater). Perangkat pembelajaran menunjang guru dan siswa meningkatkan fleksibilitas dan menawarkan pengalaman baru (Sarrab, 2012:33).

Pembelajaran berkualitas tidak cukup hanya dengan meningkatkan hasil belajar di ranah pengetahuan namun juga dalam pembentukan sikap. Sikap yang dimaksud dalam hal ini adalah Pendidikan karakter siswa Sekolah Dasar.

Pendidikan karakter siswa sekolah dasar dapat dilakukan dengan memanfaatkan lingkungan sebagai sumber belajar bagi siswa, sehingga dapat memperkuat pandangan siswa sekolah dasar tentang lingkungan. Kemampuan berpikir ilmiah siswa tentang budaya khas daerah juga perlu dikembangkan sehingga generasi masa depan tidak kehilangan jati diri bangsa Indonesia karena bijaksana, cinta dan melestarikan lingkungan.

Bentuk pembelajaran yang khas dari suatu masyarakat tertentu (Etnosains) sangat penting dimiliki oleh siswa sekolah dasar untuk mengetahui gejala yang dianggap penting dan mengorganisir dalam pembelajaran (Yuliana, 2017: 104).

Faktor-faktor yang menyebabkan kesulitan belajar siswa diantaranya adalah media massa dan internet. Media massa dan internet ternyata memberikan pengaruh yang cukup besar terhadap perkembangan belajar siswa kelas 5 SD. Ini dapat ditunjukkan dari kegiatan siswa sehari-hari baik itu di rumah maupun di sekolah. Siswa kelas 5 cenderung lebih suka bermain game, menggunakan ponsel, telepon, dan menonton televisi daripada melakukan kegiatan yang mendukung proses belajar seperti kursus, les, belajar kelompok, maupun berdiskusi dengan teman sebaya. Berdasarkan hasil wawancara pada siswa, interaksi dengan teman tidak termasuk faktor yang menyebabkan kesulitan dalam belajar ilmu alam yang dialami siswa.

Berdasarkan latar belakang dan penelitian empiris yang ada maka peneliti bermaksud menguji keefektifan mobile learning media bermuatan ethnoscience terhadap hasil belajar di Sekolah Dasar. 


\section{METODE PENELITIAN}

Data keefektifan penggunaan mobile learning media bermuatan ethnoscience dilakukan dengan uji t-test. Sebelum dilakukan uji hipotesis 1, maka perlu dilakukan pengujian tentang seberapa besar pengaruh pengembangan mobile learning media bermuatan ethnoscience pada muatan pelajaran IPA kelas 5 terhadap hasil belajar. Langkah awal dilakukan dengan membandingkan nilai pretest kelompok eksperimen dan kelompok kontrol.

Peneliti menggunakan program SPSS versi 22 untuk menguji normalitas data. Data yang digunakan merupakan hasil pretest dan posttest siswa. Data diperoleh dari kelas eksperimen (5A) dan kelas kontrol (5B).

Kemudian data nilai dari kelompok eksperimen dan kelompok kontrol (pretest maupun posttest) diuji homogenitasnya untuk mengetahui sama atau tidaknya varians dalam data tersebut.

Untuk menguji keefektifan Mobile Learning Media bermuatan Ethnoscience siswa diberikan tes pemahaman penggunaan media dengan materi "pengelompokan materi dalam kehidupan sehari-hari". Penghitungan uji t dengan program SPSS versi 22 menggunakan rumus one sample t test dengan taraf kesalahan $5 \%$.

Uji kesamaan varians dilakukan melalui uji $\mathrm{t}$ dan kesamaan rata-rata data posttest. Hasil uji t dan uji kesamaan rata-rata posttest dilakukan pengujian hipotesis 2 dengan uji dua pihak. Pengujian hipotesis dalam penelitian ini menggunakan uji kesamaan rata-rata antara kelompok eksperimen dan kelompok kontrol yang diperoleh dari nilai akhir (posttes). Uji yang digunakan adalah uji t karena telah diketahui sebelumnya data berdistribusi normal.

Uji t dilakukan untuk mengetahui kesimpulan penelitian atau hipotesis yang diterima dalam penelitian ini. Penghitungan uji t pada penelitian ini dilakukan dengan program SPSS versi 22 menggunakan rumus independent sample $t$ test dengan taraf kesalahan 5\%.

Jika dari uji sebelumnya diketahui bahwa data nilai postes kelas eksperimen dan kelas kontrol merupakan data yang berdistribusi normal dan bersifat homogen. Maka hasil penghitungan uji t dan signifikansi dibaca pada kolom Equal variances assumed.

\section{HASIL DAN PEMBAHASAN}

Mobile learning media bermuatan ethnoscience yang digunakan dalam pembelajaran merupakan produk pengembangan dari Ms.Powerpoint yang dikemas dalam wujud apk sehingga dapat diunggah dalam gawai android.

Media ini memang mencoba mengembangkan kemampuan guru dalam menciptakan media pembelajaran digital yang inovatif dan masa kini. Tujuannya agar kapasitas guru semakin berkembang. Guru perlu iklim untuk saling mengoreksi dan bertukar gagasan dalam menerapkan media pembelajaran di kelas. Apalagi untuk media pembelajaran berbasis ICT seperti ini (Nadhifah;Muslih, 2017:189). 


\section{Keefektifan Mobile Learning Media}

Maka dari itu peneliti mencoba berkolaborasi untuk membuat mobile learning media bermuatan ethnoscience untuk pembelajaran kelas tinggi khususnya di kelas 5 Sekolah Dasar. Pada gambar 1 akan ditampilkan layout depan aplikasi yang digunakan dalam pembelajaran

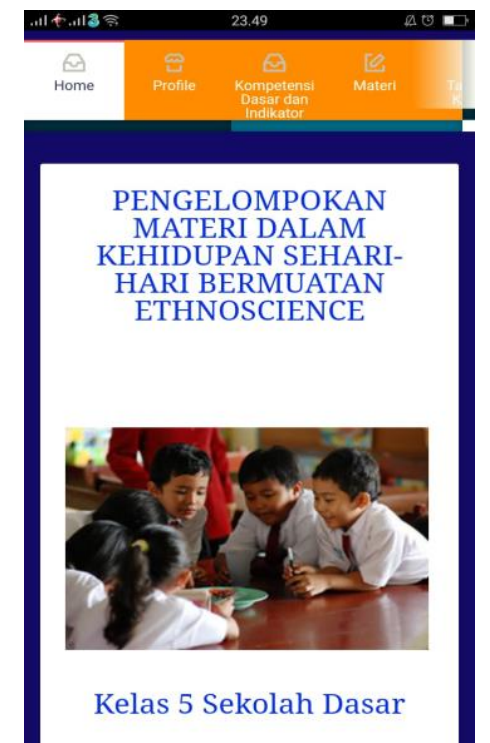

Gambar 1. Tampilan Mobile Learning Media Bermuatan Ethnoscience

Ethnoscince yang diterapkan adalah napas budaya Semarang karena penelitian dilaksanakan di SDN Sampangan 01 Kota Semarang. Adapun nilai-nilai budaya yang diambil dalam media ini adalah Lagu Gambang Semarang, Wedang Rempah Mbah Jo, serta artikel yang memuat tentang wisata kuliner Semarang.

Muatan ethnoscience dalam pembelajaran membawa pengaruh positif jika pembelajaran di sekolah yang sedang dipelajari selaras dengan pengetahuan budaya siswa sehari-hari. Proses pembelajaran tersebut dapat pula dikatakan sebagai pembelajaran inkulturasi. Pembelajaran yang berpusat pada siswa berjalan efektif karena proses asimilasi dan akomodasi belajar berjalan dengan efektif. Pembelajaran ethnoscience di Sekolah Dasar dapat membantu siswa dalam memecahkan masalah dan membantu siswa dalam berpikir kritis (Aji, 2017:9).

Kedekatan materi pembelajaran terhadap kehidupan sehari-hari terbukti mampu memudahkan siswa dalam mencapai tujuan pembelajaran. Siswa merasa lebih mudah karena hal yang dipelajari telah dialami siswa (Arfianawati, 2016:50).

Hasil perhitungan SPSS diperoleh nilai sig data pretest kelompok eksperimen adalah $0,200>0,05$. Oleh karena itu dapat disimpulkan bahwa data pretest kelompok eksperimen berdistribusi normal. Nilai sig untuk data posttest kelompok eksperimen adalah 0,057 $>0,05$ sehingga dapat disimpulkan data posttest kelompok eksperimen berdistribusi normal. 
Hasil nilai sig untuk data pretest kelompok kontrol adalah 0,09 $>0,05$ sehingga dapat diketahui bahwa data pretest kelompok kontrol berdistribusi normal. Adapun nilai sig untuk data posttest kelompok kontrol adalah 0,190 >0,05. Maka dapat disimpulkan data posttest kelompok kontrol berdistribusi normal. Hasil analisis tersebut digunakan untuk pertimbangan dalam analisis selanjutnya menggunakan statistik parametrik. Berdasarkan hasil uji normalitas tersebut maka analisis data yang digunakan untuk menguji hipotesis adalah uji independent sampel $t$ test dan uji paired sampel t-test.

Data nilai dari kelompok eksperimen dan kelompok kontrol (pretest maupun posttest) diuji homogenitasnya untuk mengetahui sama atau tidaknya varians dalam data tersebut. Hasil uji homogenitas data penelitian disajikan dalam tabel 1.

\begin{tabular}{|c|c|c|c|}
\hline Kelompok & Levene Statistic & Sig. & Kriteria \\
\hline $\begin{array}{l}\text { Pretest Eksperimen } \\
\text { Pretest Kontrol }\end{array}$ & 0,497 & 0,691 & Homogen \\
\hline $\begin{array}{l}\text { Posttest Eksperimen } \\
\text { Posttest Kontrol }\end{array}$ & 0,497 & 0,691 & Homogen \\
\hline
\end{tabular}

Berdasarkan uji homogenitas di atas, data pretest diperoleh nilai sig $=0,691>$ 0,05 . Jadi dapat disimpulkan data pretest antara kelompok eksperimen dan kelompok kontrol bersifat homogen. Sedangkan data posttest diperoleh nilai sig $=0,691>0,05$ sehingga disimpulkan data posttest antara kelompok eksperimen dan kontrol homogen juga.

Untuk menguji keefektifan Mobile Learning Media bermuatan Ethnoscience siswa diberikan tes pemahaman penggunaan media dengan materi "Pengelompokan Materi dalam Kehidupan Sehari-hari". Penghitungan uji t dengan program SPSS versi 22 menggunakan rumus one sample $t$ test dengan taraf kesalahan 5\%. Berdasarkan hasil uji t diperoleh bahwa thitu $g=28,633$ dengan sig= 0,01, sedangkan $t t e l=1,695$. Maka thitu $g>t t$ el sehingga terima $H$ yang berarti bahwa ada perbedaan antara hasil belajar kelas eksperimen dengan hasil belajar kelas kontrol dalam pembelajaran di kelas 5 dengan Mobile Learning Media Bermuatan Ethnoscience.

Uji kesamaan varians dilakukan melalui uji t dan kesamaan rata-rata data posttest. Hasil uji t dan uji kesamaan rata-rata posttest dilakukan pengujian hipotesis 2 dengan uji dua pihak.

Pengujian hipotesis dalam penelitian ini menggunakan uji kesamaan rata-rata antara kelompok eksperimen dan kelompok kontrol yang diperoleh dari nilai akhir (posttes). Uji yang digunakan adalah uji t karena telah diketahui sebelumnya data berdistribusi normal. Uji t dilakukan untuk mengetahui kesimpulan penelitian atau hipotesis yang diterima dalam penelitian ini. Penghitungan uji t pada penelitian ini dilakukan dengan program SPSS versi 22 menggunakan rumus independent sample $t$ test dengan taraf kesalahan 5\%. Pada tabel 2 ditampilkan uji hipotesis. 
Tabel 2. Penghitungan uji t

\begin{tabular}{llrr}
\hline & & \multicolumn{2}{c}{ Nilai } \\
\cline { 3 - 4 } t-test for & $\mathrm{t}$ & & Equal variances Assumed \\
Equality of & $\mathrm{df}$ & 7.718 \\
Means & Sig. (2-tailed) & 30 \\
& Mean Difference & & .000 \\
& Std. Error Difference & & 23.000 \\
& 95\% Confidence Interval & Lower & 2.978 \\
& Of the Difference & Upper & 16.919 \\
\end{tabular}

Dari uji sebelumnya telah diketahui bahwa data nilai postes kelas eksperimen dan kelas kontrol merupakan data yang berdistribusi normal dan bersifat homogen. Oleh karena itu, hasil penghitungan uji $t$ dan signifikansi dibaca pada kolom Equal variances assumed. Berdasarkan tabel diketahui nilai thitung $=7.718$ dan signifikansi $=0,001$.

Hasil penghitungan tersebut menunjukkan bahwa nilai thitung $>$ ttabel (ttable $=$ 2,045) dan signifikansi $<0,05$. Karena $7.718>2,045$ dan 0,001 $<0,05$, maka hipotesis diterima yang berarti bahwa nilai kelas eksperimen lebih baik daripada nilai kelas kontrol. Jadi, dapat disimpulkan bahwa hasil belajar kelas eksperimen yang menggunakan Mobile Learning Media bermuatan Ethnoscience lebih baik daripada hasil belajar kelas yang tidak menggunakan Mobile Learning Media bermuatan Ethnoscience.

Berdasarkan pengamatan yang dilakukan sebelum menggunakan Mobile Learning Media bermuatan ethnoscience guru kesulitan menyampaikan materi tentang campuran homogen dan campuran heterogen. Beberapa nilai siswa tidak mencapai kriteria ketuntasa minimal (KKM), namun setelah menggunakan Mobile Learning Media bermuatan ethnoscience menunjukkan bahwa belajar menggunakan Mobile Learning Media bermuatan ethnoscience berhasil dilaksanakan dengan baik dilihat dari hasil belajar siswa pada kelompok eksperimen mencapai Kriteria Ketuntasan Minimal (KKM), dengan nilai rata-rata 82,12 dan ketuntasan 85,29\%.

Hasil belajar siswa mengalami peningkatan karena adanya peningkatan motivasi dalam mengikuti pembelajaran. Pembelajaran yang dilakukan dengan menggunakan mobile learning ternyata memberikan pengalaman baru bagi siswa. Rasa ingin tahu yang tinggi memotivasi siswa untuk mengikuti proses pembelajaran dengan lebih baik. Apalagi saat siswa diberi kesempatan untuk menggunakan gawai di dalam kelas. Siswa sangat antusias dalam mengikuti pembelajaran IPA yang terangkum dalam pembelajaran tematik.

Motivasi memberikan pengaruh besar terhadap hasil belajar siswa SD yang masih dalam fase belajar sambal bermain. Sebagaimana yang disampaikan oleh (Hamdu, 2011, p. 95) bahwa secara umum motivasi belajar besar pengaruhnya 
terhadap prestasi belajar IPA dari siswa. Pembelajaran yang dikemas menarik telah memberikan pengaruh signifikan terhadap hasil belajar siswa.

Di era global guru memang perlu mencari keselarasan antara media pendidikan dengan teknologi sebagai bagian dari alternatif memajukan kehidupan bangsa (Hardiansyah, 2018, p. 329). Keberadaan mobile learning sebagai media belajar merupakan produk pengembangan integrasi teknologi di dalam pembelajaran.

Unsur kebudayaan yang dimasukkan ke dalam pembelajaran IPA lebih dikenal dengan istilah ethnoscientifict (Guzey;Roehrig, 2009:53)(Guzey;Roehrig, 2009). Fokus mendasar dari etnosains adalah sudut pandang orang asli, hubungan mereka dengan kehidupan untuk mewujudkan visinya tentang dunia.

Sains dapat dijadikan alat manusia belajar tentang lingkungan, sumber daya dan segala pemanfaatannya. Integrasi antara sains, budaya, teknologi, dan media pembelajaran yang berkelanjutan merupakan modal dalam membentuk generasi unggul dan berbudaya.

Kerjasama guru, sekolah, dan orang tua merupakan kunci keberhasilan mendidik anak. Apalagi di usia SD, anak masih membutuhkan riil modele dalam menemukan jati dirinya saat ini. Pengalaman yang diterima anak saat ini adalah modal untuk menghadapi dunia global di masa mendatang.

\section{SIMPULAN}

Pembelajaran menggunakan mobile learning media bermuatan ethnoscience terbukti efektif untuk meningkatkan hasil belajar siswa khususnya pada muatan pelajaran IPA kelas 5 SD. Nilai thitung $>$ ttabel (ttable $=2,045)$ dan signifikansi $<0,05$. Karena $7.718>2,045$ dan 0,001 $<0,05$, maka hipotesis diterima yang berarti bahwa nilai kelas eksperimen lebih baik daripada nilai kelas kontrol. Jadi, dapat disimpulkan bahwa Mobile Learning Media bermuatan Ethnoscience efektif untuk digunakan di sekolah dasar.

\section{DAFTAR RUJUKAN}

Aji, S. J. (2017). Etnosains dan Peranannya Dalam Menguatkan Karakter Bangsa. 7-11. Retrieved from http://e-journal.unipma.ac.id/index.php/snpf

Arfianawati, S. S. S. (2016). Model Pembelajaran Kimia Berbasis Etnosains Untuk Meningkatkan Kemampuan Berpikir Kritis Siswa. Jurnal Pengajaran MIPA, 21, 46-51. https://doi.org/: http://dx.doi.org/10.18269/jpmipa.v21i1.669

Guzey;Roehrig. (2009). Teaching Science with Technology: Case Studies of Science Teachers' Development of Technology, Pedagogy, and Content Knowledge. Contemporary Issues in Technology and Teacher Education, 9, 25-45. Retrieved from https://citejournal.s3.amazonaws.com/wpcontent/uploads/2016/04/v9i1science1.pdf

Hamdu, G. L. A. (2011). Pengaruh Motivasi Belajar Siswa Terhadap Pestasi Belajar Ipa Di Sekolah Dasar (Studi Kasus terhadap Siswa Kelas IV SDN Tarumanagara 
Kecamatan Tawang Kota Tasikmalaya). Jurnal Penelitian Pendidikan, 12, 9096. Retrieved from http://jurnal.upi.edu/file/8-Ghullam_Hamdu.pdf

Hardiansyah, H. W. (2018). Pengembangan Bahan Ajar Berbasis Mobile Learning. 327331. Retrieved from http://journal.unj.ac.id/unj/index.php/psdpd/article/view/10155/6582

Ibda, Hamidulloh. (2018). Penguatan Literasi Baru Pada Guru Madrasah Ibtidaiyah Dalam Menjawab Tantangan Era Revolusi Industri 4.0. JRTIE: Journal of Research and Thought of Islamic Education, 1, 1-19. Retrieved from https://jurnaliainpontianak.or.id/index.php/jrtie/article/view/1064

Mohamed Ally. (2009). Mobile Learning Transforming the Delivery of Education and Training. Retrieved from http://citeseerx.ist.psu.edu/viewdoc/download?doi=10.1.1.475.2163\&rep=re p1\&type $=$ pdf

Nadhifah;Imam Muslih. (2017). Peningkatan Kapasitas Guru dalam Mengembangkan Media Pembelajaran Information and Communication Technology (ICT) di Madrasah Ibtidaiyah Thoriqul Huda Randuharjo Pungging Mojokerto. MODELING: Jurnal Program Studi PGMI, 2, 172-191. Retrieved from http://jurnal.stitnualhikmah.ac.id/index.php/modeling/article/view/127/11 9

Nasution, M. I. F. (2016). Strategi Pembelajaran Efektif Berbasis Mobile Learning Pada Sekolah Dasar. Iqro Jurnal Perpustakaan Dan Informasi, 10, 1-14. https://doi.org/http://jurnal.uinsu.ac.id/index.php/iqra/article/view/123/1 03

Prawiradilaga. (2012). Wawasan Teknologi Pendidikan. Jakarta: Kencana Prenada Media Group.

Sarrab, M. (2012). Mobile Learning (M-Learning) and Educational Environments. International Journal of Distributed and Parallel Systems (IJDPS), 3, 31-38. Retrieved from https://pdfs.semanticscholar.org/351c/5ff846b519ba00a8219f50a4730f3f40 c10d.pdf

Yuliana, I. (2017). Pembelajaran Berbasis Etnosains Dalam Mewujudkan Pendidikan Karakter Siswa Sekolah Dasar. ELSE (Elementary School Education Journal): Jurnal Pendidikan Dan Pembelajaran Sekolah Dasar, 1, 98-106. Retrieved from http://journal.um-surabaya.ac.id/index.php/pgsd/article/view/1051/730.

MODELING, Volume 6, Nomor 2, September 2019 | 136 